\title{
METODE DATA DISPLAY DALAM PRELIMINARY SURVEY LAPANGAN DI TK TUNAS BANGSA (SUMBERMANJING WETAN, MALANG)
}

\author{
Ghoustanjiwani Adi Putra \\ Dosen Prodi Arsitektur, Fak. Teknik Sipil dan Perencanaan, ITN Malang \\ e-mail: ghoustanputra@lecturer.itn.ac.id \\ Tutut Nani Prihatmi \\ Dosen Prodi Teknik Mesin S1, Fak.Teknik Industri, ITN Malang \\ e-mail: tututnani@lecturer.itn.ac.id \\ Hani Zulfia Zahro \\ Dosen Prodi Informatika, Fak.Teknik Industri, ITN Malang \\ e-mail: hani.zulfia@lecturer.itn.ac.id
}

\begin{abstract}
ABSTRAK
Desa Harjokuncaran memiliki jumlah penduduk sebesar 11.200 jiwa, yang terdiri dari 3250 KK, dengan jumlah total Gakin/binaan sebanyak 600 jiwa. Desa Harjokuncaran juga masih memiliki angka kemiskinan cukup tinggi disertai tingkat pendidikan yang mayoritas rendah, hal ini dapat dilihat dari keterbatasan fasilitas pendidikan yang memadai. Salah satu fasilitas pendidikan ini adalah PAUD Tunas Bangsa 02 yang merupakan obyek studi kasus pada penelitian ini. Pada survei awal ini pengumpulan data dilakukan dengan cara observasi langsung dilapangan dan didukung dengan wawancara langsung. Data kualitatif yang terkumpul disortir dengan teknik pengelompokan data melalui content analisis. Data data yang telah di sortir melalui content analisis tersebut akan ditampilkan dengan metode data display dan disajikan dalam bentuk pengelopokan data berdasarkan variabel dan conten data. Tahap penelitian kualitatif ini hanya sebatas Preliminary Survey. Pada tahap ini penelitian akan hanya terfokus dalam perolehan data. Data data yang didapat dalam Preliminary Survey antara lain: data terkait kondisi wilayah, data karakteristik fisik spasial, dan data karakteristik sosial. Ketiga jenis data ini akan digunakan sebagai data awal dalam menentukan proses penelitian selanjutnya di waktu yang akan datang. Dimana penelitian yang akan datang akan berfokus dalam pengolahan data tersebut sebagai data awal untuk merencanakan dan merancang fasilitas pembelajaran pada studi kasus Paud Tunas bangsa 02.
\end{abstract}

Kata kunci : ruang pembelajaran, Preliminary Survey, Data Display 


\begin{abstract}
With a population of 11,200 people, Harjokuncaran village still has a reasonably high poverty rate accompanied by a low majority of education levels. This condition can be seen from the educational facilities and environment, especially in early childhood education institutions. One example is in PAUD Tunas Bangsa 02 as the study object in this research. Data collection was carried out by field observation and direct interviews. The collected qualitative data are sorted by content analysis, displayed using the data display method and presented in data grouping. This qualitative research stage was only limited to the Preliminary Survey. At this preliminary stage, the research will only focus on obtaining data, include regional conditions, spatial, and physical and social characteristics data. These three types of data will be used as initial data in determining the next research process in the future.
\end{abstract}

Keywords : Learning Space, Preliminary Survey, Data Display

\title{
1. PENDAHULUAN
}

Pendidikan yang didapat dari proses pembelajaran untuk anak adalah merupakan hak yang paling mendasar dan utama dalam pola perkembangan karakter anak dalam usia tumbuhnya. Keluarga merupakan ruang sosial terkecil dalam pengembangkan pendidikan anak, namun diperlukan suatu media pembelajaran diluar ruang sosial terkecil mereka. Dengan belajar di sekolah PAUD, anak lebih bisa belajar untuk bersosialisasi dengan rekan seusia, menghormati guru dan orang lebih tua, dan mampu berpikir kreatif dengan berbagai permainan dan pendampingan selama di sekolah. Sehingga, salah satu faktor utama meningkatkanya taraf hidup di Desa Harjokuncaran adalah pendidikan, yang dimulai dari pendidikan usia dini, agar generasi muda Harjokuncaran lebih siap untuk menempuh pendidikan lanjut, sekaligus memiliki karakter yang unggul dan akhlak yang baik.

Faktor pendukung program adalah meningkatnya kesadaran masyarakat Desa Harjokuncaran akan pentingnya pendidikan anak usia dini, sehingga mereka tidak merasa memiliki keraguan untuk menitipkan anak-anak pada POS PAUD maupun TK/RA. Selain itu pemerintah juga mendukung dengan melakukan sosialisasi berkala mengenai pentingnya pendidikan usia dini. Dukungan pemerintah ini melalui dinas pendidikan dengan memberikan pelatihan-pelatihan, seminar, dan workshop baik untuk pengelola POS PAUD maupun guru dan tenaga pendidik pada lembaga PAUD. Tujuan dari pemerintah dengan mengadakan sosialisasi dan program pelatihan tersebut diharapkan lembaga PAUD tersebut dibekali kemampuan khusus untuk perkembangan pembelajaran sehingga lembaga PAUD tersebut diharapkan

PAWON: Jurnal Arsitektur, Nomor 01 Volume V, Januari-Juni Tahun 2021, ISSN 2597-7636 
mampu memberikan layanan yang optimal bagi masyarakat desa Harjokuncaran.

Di desa Harjokuncaran sendiri dapat dikatakan memiliki kesadaran warga yang cukup tinggi untuk menyekolahkan anak-anak mereka pada lembaga PAUD maupun TK/RA. Hal ini dapat dibuktikan dengan angka kenaikan jumlah siswa yang mendaftar pada 6 sekolah usia dini baik PAUD dan RA di desa Harjokuncaran. Tentunya hal ini mampu menjadi kontribusi positif pada peningkatan mutu sumber daya manusia desa Harjokuncaran secara menyeluruh.

Desa Harjokuncaran sendiri memiliki jumlah penduduk sebanyak 11.200 jiwa dengan total $3250 \mathrm{KK}$, dan memiliki Gakin/binaan sebanyak lebih dari 600 jiwa. Namun sayangnya desa Harjokuncaran dapat dikatakan masih memiliki angka kemiskinan cukup tinggi, disertai dengan tingkat pendidikan yang mayoritas masih rendah, hal ini juga dipengaruhi oleh angka putus sekolah yang masih cukup tinggi.

Kondisi angka kemiskinan yang rendah dengan tinngkat pendidikan yang rendah tersebut menyebabkan rendahnya angka pekerja yang layak di desa Harjokuncaran. Hal ini tidak bisa terlepas dari mayoritas warga yang hanya bekerja sebagai buruh tani maupun kuli bangunan, sopir, dan tenaga kerja kasar. Oleh karena itu, peningkatan kualitas pendidikan yang dimulai dari pendidikan sejak usia dini, dan penciptaan lapangan pekerjaan yang lebih beragam dengan menciptakan wirausaha baru merupakan hal yang sangat dibutuhkan untuk diterapkan dan dilaksanakan di desa ini.

Berangkat dari latar belakang kondisi desa Harjokuncaran tersebut, perbaikan fasilitas pembelajaran khususnya pada PAUD dan TK/RA sangat diperlukan. Salah satu Fasilitas pendidikan ini adalah PAUD Tunas Bangsa dimana PAUD ini merupakan fasilitas pendidikan usia dini yang ber alamatkan pada dusun Prangas Rt.29 Rw.04 Desa Klepu Kecamatan Sumbermanjing Wetan, Kabupaten Malang.

Pada ulasan ini penulis akan mengulas bagaimana metode display data dalam sebuah research atau penelitian. Ulasan penulis ini sebagai salkah satu proses penelitian dan pengabdian masyarakat dalam proses preleminaries research atau survei awal. Dalam kegiatan pengabdian masyarakat ini penulis telah melakukan tinjauan lokasi pada studi kasus pada PAUD Tunas Bangsa desa Harjokuncaran.

\section{TINJAUAN PUSTAKA}

Metodologi dapat di artikan sebagai "a body of methods and rules followed in science or discipline". Kata dasar "metode" dapat diartikan sebagai: "a regular systematic plan for or way of doing something". Kata ini

PAWON: Jurnal Arsitektur, Nomor 01 Volume V, Januari-Juni Tahun 2021, ISSN 2597-7636 
berasal dari bahasa Yunani yaitu methodos (meta dan bodos) yang dapat diartikan sebagai cara. Metode kualitatif dapat disimpulkan adalah sebuah metode pendekatan dalam sebuah penelitian yang umumnya digunakan untuk mengurai fenomena secara kualitatif.

Sedangkan metode ini juga dapat dikatakan sebagai inti utama dari penelitian kualitatif yang berdasarkan fenomena tertentu, atau obyek studi kasus tertentu hingga pada akhirnya didapat sebuah pemahaman mendasar dan mendalam pada lingkup studi kasus yang dijadikan fokus tematik penelitian kualitatif tersebut, pendalaman pad afenomen dan studi kasus ini meliputi pendekatan pada studi kasus secara menyeluruh hingga didapat simpulan pemahaman studi kasus yang ebih dalam.

\section{Preliminary Survey Dan Display Data}

Survey pendahuluan dapat diartikan sebagai proses pada sebuah penelitian yang bertujuan untuk mendapatkan pemahaman yang lebih mendasar dan mendalam mengenai fenomena maupun masalah dari suatu obyek kasus yang akan diteliti.

Dalam survei pendahuluan ini, fenomena utama tidak akan digali dan dibedah secara langsung melainkan hanya diamati secara langsung namun tidak pada taham simpulan. Survey ini bertujuan untuk memperoleh data awal pada obyek studi kasus atau fenomen terpilih, selain itu stud awal adalah sebagai bagian yang cukup penting dalam bahan kajian teknis. Hasil dari proses survei pendahuluan ini merupakan base data yang akan dijadikan salah satu bahan dasar untuk tahap penelitian selanjutnya. Survei ini diharapkan mampu memberikan saran berupa simpulan sementara sebagai bahan dasar data dab pertimbangan terhadap survei yang lebih detail proses penelitian lanjutan.

Data data dari hasil preliminary survey yang telah terkumpul tahap selanjutnya adalah dilakukan pengelompokan data secara terstruktur. Pengelompakan data-data ini berdasarkan konten dan variabel yang telah dikelompokan sebelum dilakukan proses selanjutnya yaitu data display.

Sedangkan Menurut (Miles \& Huberman, 1992) bahwa data yang telah direduksi melaui pengelompokan yang terstruktur, maka proses selanjutnya adalah pemaparan data atau mendistribusikan data kedalam bentuk diplay baik secara desktriptif maupun grafis. Pemaparan data tersebut dapat disebut sebagai sekumpulan informasi dan proses distribusi data tersusun yang lebih menarik dan gampang dipahami. Pada proses display data ini diharapkan mampu memberi kemungkinan-kemungkinan adanya penarikan kesimpulan sementara. Selain adanya penarikan kesimpulan sementara tersebut langkah selanjutnya adalah memberikan berbagai kemungkinan tahapan penelitian selanjutnya. Penyajian data atau display data merupakan 
sekumpulan hasil survei awal yang menjadi base ata sebagai informasi yang tersusun dan terstruktur.

Bentuk penyajian data pada data display dapat berupa deskriptif data, essay, hasil wawancara yang diolah dalam bentuk matriks, grafik, jaringan, began, tabulasi dan lain-lain. Informasi yang tersusun dalam suatu bentuk untuk mempermudah dilakukan analisis.

\section{PEMBAHASAN}

Berdasarkan Preliminary Survey berbasis data monografi pada kelurahan setempat, penulis dapat mengumpulkan data data mengenai kondisi wilayah terkait Studi kasus antara lain:

1. Data terkait kependudukan. Desa Harjokuncaran memiliki jumlah penduduk sebanyak 11.200 jiwa, disertai dengan total $3250 \mathrm{KK}$.

2. Data terkait Pendidikan. Desa Harjokuncaran Memiliki 5 SD/sederajad, 3 SMP/sederajad, 4 TK/RA, dan 2 PAUD. Dimana 1 diantara 2 Paud ini dipilih peneliti sebagai studi kasus, yaitu PAUD Tunas Bangsa 02.

3. Data terkait Kesehatan. Desa Harjokuncaran memiliki programprogram yang terkait dengan kesehatan. Program program ini antara lain: PMT Anak Sekolah bagi 3 SDN dan 2 MI, Desa Siaga, Bumil-Bayi-Balita, KIA, KB, Imunisasi, Ibu nifas \& menyusui, serta progam terkait dengan Gizi.

4. Data terkait Keagamaan. Desa Harjokuncaran memiliki 94 Sarana ibadah meliputi 7 masjid dan 86 unit langgar/surau juga 1 Gerja. Sedangkan Fasilitas pembelajaran yangterkait dengan keagamaan adalah 39 unit TPQ.

5. Selain itu Desa Harjokuncaran juga didukung dengan berbagai pengajian tahlilan putra putri yang dilakukan rutin tiap minggu di tiap RT, dengan jamaah istighotsah tiap RW, sholawat Asyrofarrosul, Remas, Diba'an di tiap-tiap RW, dan berbagai kegiatan keagamaan dan sosial termasuk santunan yatim piatu dan Haul Akbar tiap tahun. 


\section{Data display dalam Analisis Situasi}

Analisa situasi adalah analisa pada studi kasus yang dilakukan baik pada proses survei awal maupun survei utama dimana analisa ini bertujuan untuk mendapatkan gambaran kondisi real pada studi kasus. Kondisi ini dapat berupa potensi, kendala, masalah, kelebihan dan kekurangan studi kasus yang ada pada lokasi dimana hasil analisa ini dapat digunakan sebagai acuan untuk merumuskan data awal pada penelitian. Jenis analisa situasi ini juga bisa digolongkan kedalam proses Preliminary Survey, karena analisis ini masih bersifat memberikan gambaran studi kasus di awal penelitian. Analisis situasi merupakan analisis yang menggambarkan keadaan studi kasus. Analisis situasi dibagi kedalam 3 jenis data antara lain:
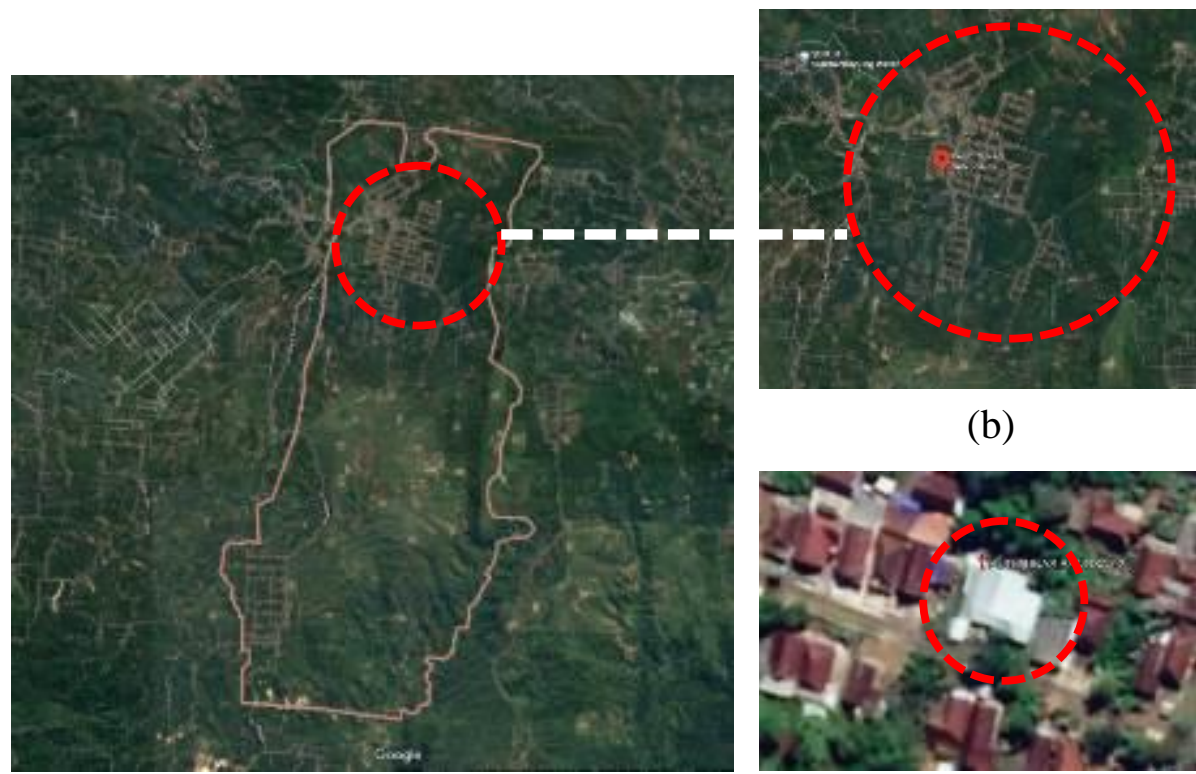

(b)

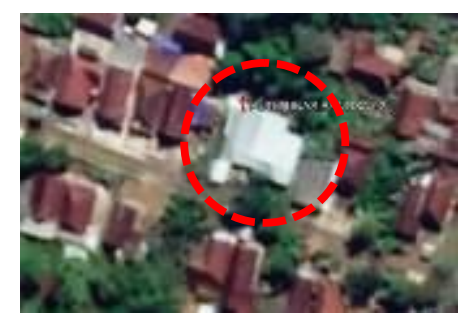

Gambar. 1

DATA DISPLAY: ANALISIS SITUASI

Sumber: (Google earth)

Studi kasus Paud Tunas Bangsa 02 terletak di Desa Harjokuncaran. Desa ini terletak pada kabupaten Malang dengan jarak $3 \mathrm{~km}$ ke arah timur dari Kecamatan Sumbermanjing Wetan. Desa Harjokuncaran Terdiri atas 2 dusun yaitu Krajan dan Mulyosari.

- Makro (b) Studi kasus Paud Tunas Bangsa 02 terletak di daerah padat penduduk diantaranya terletak berbagai fasilitas pendidikan seperti SDN Sumbermanjing Wetan.

- Mikro (c). Studi kasus Paud Tunas Bangsa 02 terletak di daerah padat penduduk dengan kondisi fisik sarana jalan yang cukup buruk.

Data display dalam data Karakteristik Fisik Spasial

PAWON: Jurnal Arsitektur, Nomor 01 Volume V, Januari-Juni Tahun 2021, ISSN 2597-7636 
Dalam (Putra, 2020) Physical characteristics may describe as the first dimensions spatial form and social characteristics which may related as the third dimensions of spatial form, dimana karakteristik fisik dapat di gambarkan kedalam bentuk kualitas fisik sebuah obyek yang bersifat padat $3 d$. Dalam penelitian tersebut dapat disimpulkan bahwa dalam menganalisa karakteristik fisik spasial dapat dilakukan dengan menganalisa visual yang wajib dilakukan dengan pengamatan langsung pada studi kasus yang di pilih

Gambar 2. Karakteristik Fisik Spasial PAUD Tunas Bangsa 2

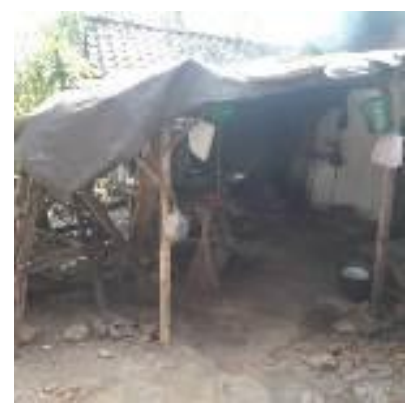

A

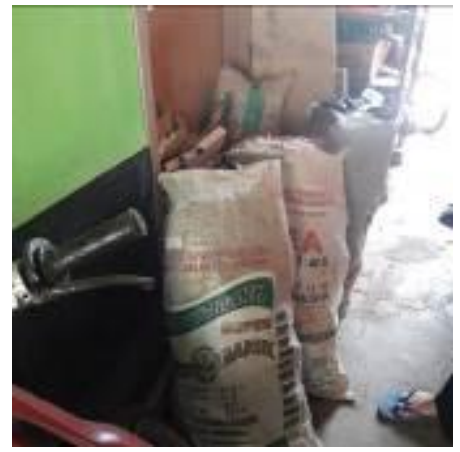

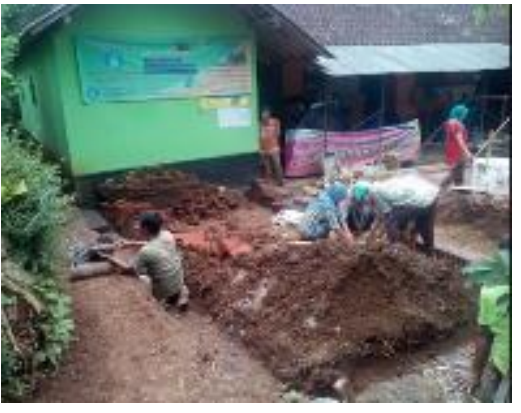

B

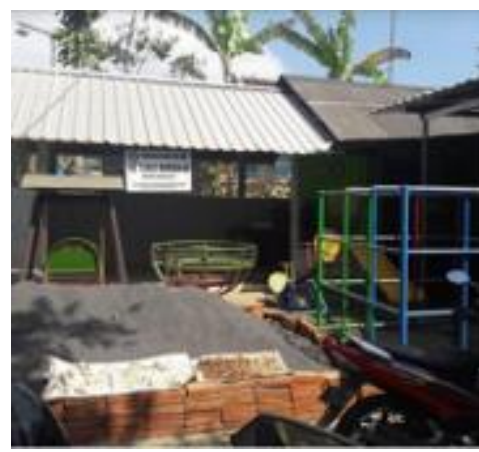



Dari pengamatan awal ini peneliti pada studi awal ini dapat mengambil berbagai poin amatan yang terkait dengan karakteristik fisik spasial antara lain:

1. Kondisi awal tahun 2016 PAUD Tunas Bangsa 02 memiliki kekurangan kualitas fisik yang sangat kurang representatif untuk kegiatan belajar mengajar, hal ini dikarenakan adanya berberapa elemen visual yang cukup mengganggu seperti kayu bakar, kain penutup (terpal), batu dll. (a)

2. Karakteristik fisik spasial dari PAUD Tunas Bangsa pada survei awal ini dapat dikategorirkan kedalam karakteristik fisik spasial dengan kondisi visual yang cukup buruk. 
3. Menurut pemilik diawal tahun 2017 Paud diawali secara swadaya oleh pemilik paud tersebut hingga mendapat bantuan secara berturut-turut tiap tahunya.

4. Hingga pada pertengahan 2018 bantuan dari pemerintah dan berberapa sumbangan swadaya dari masyarakat setempat PAUD Tunas Bangsa mengalamii perbaikan yang cukup siknifikan. Berbagai perbaikan ini antara lain penambahan Aula bersama, penambahan keramik pada ruang ajar, Perbaikan Kamar mandi, hingga penambahan Alat-alat bermain anak serperti jungkat jungkit, perosotan hingga plang warni warni.

5. Hingga survei awal yang telah dilakukan pada akhir 2019 hingga awal 2020 kondisi PAUD Tunas Bangsa 02 masih memerlukan perbaikan

6. Pada Akhir 2020 hingga awal 2021, dengan adanya pandemi Covid 19 kegiatan PAUD sempat menurun sehingga aktifitas pada PAUD mengalami penurunan.

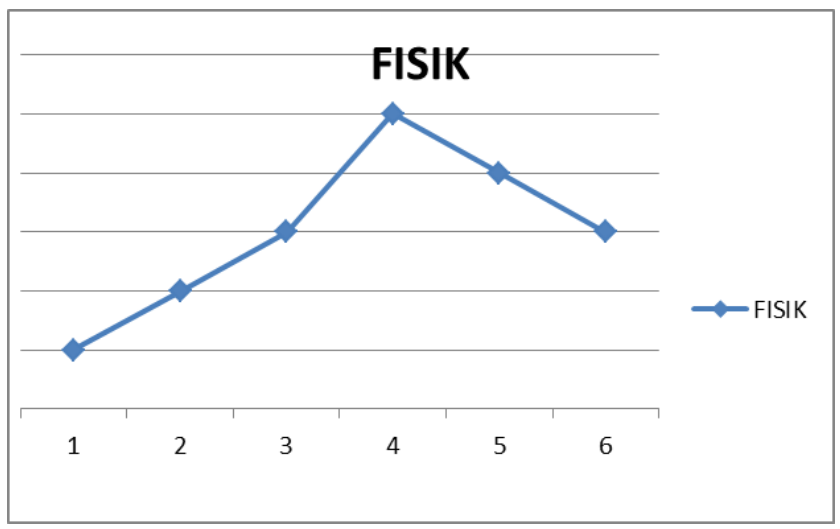

FIGURE 1. Kenaikan dan Penuruan Fasilitas fisik PAUD Tunas Bangsa 2

\section{Data Display dalam Data Karakteristik Sosial}

Dalam (Hani Zulfia Zahroh, 2019), karakterisitik sosial dalam spasial dapat diartikan sebagai sosio kultur dari dimensi sosial setempat. Sedangkan yang dimaksud dengan dimensi sosial setempat sendiri dapat diartikan pengguna spasial pada studi kasus. Analisis karakteristik sosial ini sudah pernah di teliti pada penelitian yang berbasis pengabdian masyarakat yang mengambil studi kasus Kampung tematik Sumbersari Malang. Peneliti menemukan aktifitas pengguna pasif dan aktif dapat membentuk sosio kultur yang kuat antar pengguna ruang. 
Sama seperti halnya dengan penelitian-penelitian sebelumnya, pada survel awal ini ditemukan berbagai analisis data yang terkait dengan karakteristik sosial antara lain:
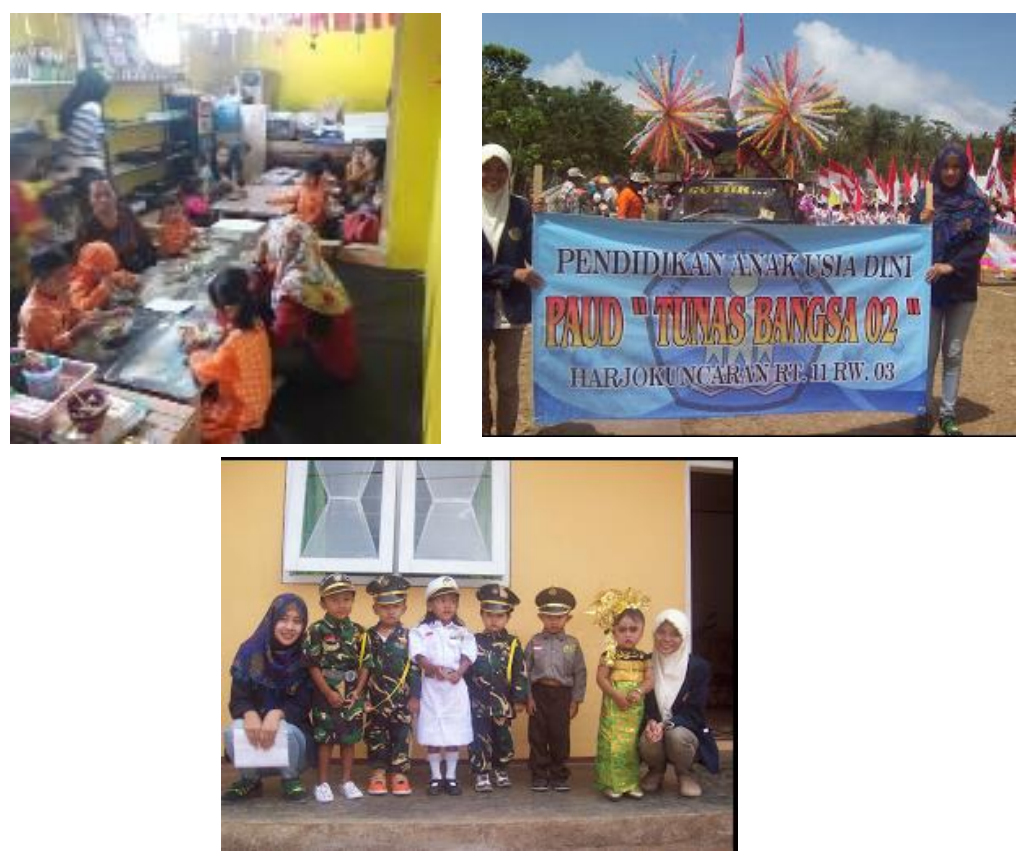

(a)

(b)

(c)

Gambar 3. Karakteristik Sosial PAUD Tunas Bangsa 02

- Karakteristik sosial pada studi kasus berdasarkan Pengembangan materi karakter yang akan menjadi tujuan dari proses pembelajaran dapat ditentukan berdasarkan identifikasi karakter pengguna. Dalam hal ini pengguna ruang baik ruang luar maupun ruang dalam adalah siswa, guru, dan orangtua siswa.

- Karakteristik dari siswa PAUD Tunas Bangsa 2 sangat bervarian, hal ini di sebabkan perkembangan anak yang berbeda-beda dari pola asuh masing masing wali murid. Dalam

- Karakter merupakan variabel yang sangat sulit diukur, bahkan dengan dalam analisa psikologis sekalipun. Namun untuk bisa merancang sebuah fasilitas pembelajaran dengan berdasarakn pembentukan karakter yang tepat, harus diukur tidak hanya dari karakteristik fisik pada ruang pembelajaran namun juga karakteristik sosial. 


\section{KESIMPULAN}

Dari pengamatan awal ini peneliti pada studi awal ini dapat mengambil berbagai poin amatan yang terkait dengan data data di lapangan antara lain:

1. Berdasarkan analisis situasi pada preleiminary survey dapat digolongkan menjadi 3 jenis data antara lain:

a. Data Terkait Kondisi Wilayah

b. Data Terkait Karakteristik Fisik Spasial

c. Data Terkait Karakteristik Sosial

2. Masing masing data tersebut mampu berubah baik bertambah dan berkurang berdasarkan waktu dan kebaruan data.

3. Ketiga jenis data tersebut pada survei awal ini akan digunakan sebagai base data dalam menentukan proses penelitian selanjutnya di waktu yang akan datang.

4. Penelitian yang akan datang dimungkinakan akan berfokus dalam pengolahan ketiga data tersebut

5. Penelitian selanjutnya dimungkinkan akan berfokus dalam merencanakan dan merancang fasilitas pembelajaran pada studi kasus Paud Tunas bangsa 02.

\section{DAFTAR PUSTAKA}

Hani Zulfia Zahroh. (2019). Desain Partisipasi Dalam ruang Publik, Ruang komunal Sosial Dalam Kampung Heritage Tawangsari Sebagai Salah Satu Bentuk Aplikasi Unsur Keberlanjutan Sosial. PAWON.

Miles, B., \& Huberman, M. (1992). Analisis Data Kualitatif Buku Sumber Metodemetode Baru. Jakarta: UIP.

Putra, G. A. (2020). Observations of spatial and physical characteristics in the public space environment as a measurement parameter of visual comfort. ESE International Journal (Environmental Science and Engineering), 03(1), 2326.

UNESCO, T. S. (2005). Laporan Review Kebijakan : Pendidikan dan Perawatan Anak Usia Dini di Indonesia (Vol. 1). (W. U. Jakarta, Ed.) Jakarta, Jakarta, Indonesia: Direktorat Jenderal Pendidikan Luar Sekolah dan Pemuda Departemen Pendidikan Nasional Indonesia. 